\title{
UDC 656.225
}

\author{
D. M. KOZACHENKO ${ }^{1 *}$, R. V. VERNIGORA ${ }^{2 *}$, R. S. RUSTAMOV ${ }^{3 *}$ \\ ${ }^{1 *}$ Research Department, Dnipropetrovsk National University of Railway Transport named after Academician V. Lazaryan, \\ Lazaryan St., 2, Dnipro, Ukraine, 49010, tel. +38 (056) 37351 09, e-mail kozachenko@upp.diit.edu.ua, \\ ORCID 0000-0003-2611-1350 \\ ${ }^{2 *}$ Dep. «Stations and Nodes», Dnipropetrovsk National University of Railway Transport named after Academician V. Lazaryan, \\ Lazaryan St., 2, Dnipro, Ukraine, 49010, tel.+38 (056) 37315 12, e-mail rv.vernigora@gmail.com, \\ ORCID 0000-0001-7618-4617 \\ ${ }^{3 *}$ The Regional Branch of the «Odesa Railroad» PJSC «Ukrzaliznytsia», Panteleymonivska St., 19, Odesa, Ukraine, \\ tel. +38 (048) 72730 96, e-mail rustamovrsh@gmail.com, ORCID 0000-0002-5860-1840
}

\section{CREATION OF EXPORT-ORIENTED NETWORK OF GRAIN ELEVATORS IN UKRAINE}

Purpose. The scientific paper highlights improving the efficiency of export rail transportation of grain cargoes in Ukraine by introducing shipper routing and concentration of loading at the terminal grain elevators. Methodology. According to the experience of the USA and Canada, one of the most effective ways to reduce costs in the grain to-port supply chain is a shipper routing of the rail traffic. Shipper routing for transportation of grain cargoes involves the concentration of their loading on the multiple junctions. The junctions are proposed to be selected with the use of cluster analysis methods. For the formation of the grain loading concentration areas the authors used methods of set theory and multi-criteria optimization. Findings. Based on agglomerative cluster analysis algorithm, the junctions on a network of Ukrainian railways are selected and the areas of possible concentration of grain loading are formed. DSU-algorithm allowed distinguishing the overlapping and non-overlapping areas of concentration. The problem of selecting non-overlapping areas of the grain loading concentration is formalized as the problem of multiobjective integer programming with boolean variables. The solution of this problem by a modified simplex algorithm allows selecting on the railway network of Ukraine 24 districts of possible grain loading concentration, which cover 70 stations and at minimal additional cost provide routing of about 7.5 million tons of grain per year. Originality. The originality of the work lies in the fact that the authors developed the mathematical procedure for selection of junctions and concentration areas of grain loading at the Ukrainian railway network, taking into account the economic efficiency of the process. Practical value. Application of the developed method of grain loading concentration for the formation of unit trains will significantly reduce the logistics costs in the supply chain of grain to Ukrainian ports for export and, consequently, increase its competitiveness in foreign markets.

Keywords: grain export; elevators; rail transportation; shipper routing; loading concentration

\section{Introduction}

Grain is one of the main export goods of Ukraine. Over the period from 2006 to 2016, the share of its value in the total value of goods exported from Ukraine increased from 3.5 to $16.5 \%$. In 2015/2016 marketing year among grain exporters, Ukraine, with an indicator of 38.7 million tons, took the third place, behind the United States (78.5 million tons) and the European Union (52.2 million tons). Significant volumes of grain were exported by Argentina (36.2 million tons), the Russian Federation (34.6 million tons), Canada (27.7 million tons) and other countries [14]. One of the ways to increase the competitiveness of domestic grain in the world market is to build an effective logistics system. For Ukraine, this task is espe- cially important, as the share of logistics costs in the cost of domestic grain is about $35 \%$; for comparison, the share of logistics costs in the grain cost in the European Union is $12-16 \%$, the United States $-9 \%$ [10].

In 2016 in Ukraine, about $97 \%$ of grain exports were made through seaports, while $63 \%$ of grain cargo was delivered to sea ports by rail. Therefore, increasing the efficiency of grain cargo transporting by rail and water transportation is one of the key tasks that must be addressed to reduce logistics costs. The need to develop logistic schemes for the grain delivery to ports with the participation of rail transport is also conditioned by the need to increase Ukraine's energy independence. The railway 
transport of Ukraine performs about $90 \%$ of the turnover of electric power with the use of domestic energy carriers. On the contrary, $72 \%$ of oil products consumed in Ukraine are used for the needs of motor transport; while $80 \%$ of oil products are imported by Ukraine [4].

Significant progress in reducing the cost of grain transportation was achieved in the US and Canada in the late 20th, early $21^{\text {st }}$ century.

Changes in grain logistics in the United States began in 1972-1973 in response to a sharp increase in demand for grain in the world market [25]. These changes led to a change in the number, capacity and location of elevators throughout the country, improvement of the technology of grain transportation by railways and their tariff systems. Similar changes have occurred since the 1980s in Canada.

Prior to the reform process, the logistics system for grain delivery by the North American railways was similar to that operating on the Ukrainian railways. Empty carriages for the transportation of grain were sent to technical stations, where from the groups of 1 to 25 wagons were approached to the loading stations. After loading, the wagons were sent to technical stations for making up of trains according to the composition plan. In 1965, the USA began to use technology to transport grain for export to seaports by route shipments [23]. The efficiency of grain transportation by routes is connected with a reduction of station costs, the more rational use of the capacity of wagons and the throughput and carrying capacity of railways. At the same time, this technology requires the development of access roads and loading capacity of elevators [20].

Further technical and technological innovations, state policy aimed at market development led to a change in the volume, quality and cost of railroad services associated with the transportation of grain. The end of the $1970 \mathrm{~s}$ - the beginning of the 1980s was the period of economic deregulation of the railway transport. The US Congress adopted a number of documents, the most important of which were: "Railroad Revitalization and Regulatory Reform Act" of 1976 [24] and "Staggers Rail Act" of 1980 [28]. These laws significantly simplified for the railways the procedure for closing inactive areas and also gave considerable freedom in the for- mation of tariff policy. As a result, inactive areas, which constituted about $20 \%$ of the network, were closed, in addition a significant number of lowactivity sections were converted into railways, independent of the 1st class railways [29]. Tariff policy of railways has also undergone significant changes. The railways switched from tariffing of freight in proportion to the ton of cargo to singlecar rate, multiple-car rates, unit train and multiple origin unit train rates, stimulating shippers, on the one hand, to the maximum loading of wagons, and, on the other hand, to the concentration of grain traffic. In the 1990s, the Burlington Northern railway (BNSF after 1996) introduced the technology of grain transportation by shuttle train [22]. This technology implies the use of a special tariff, which is lower than that for the transportation of grain by group shipments by $46-52 \%$. At the same time, the shipper must be able to ensure loading of the train of 75-120 cars during the limited time (about 15 hours) [27]. Trains move between the points of loading and unloading according to a rigid schedule in accordance with the contract for 6-9 months, without remarshaling and uncoupling of train locomotives at the loading station [26]. In response to changes in grain transportation conditions in the United States, there were significant changes in grain production and storage systems. Between 1980 and 1998, the number of agricultural enterprises decreased by $15 \%$, while their size increased by $11 \%$. The total number of elevators decreased due to a significant reduction in the number of country elevators, while the number of terminal elevators increased, and the number of terminal elevators increased, ensuring the shipment of grain to the railway transport in lots sufficient for the formation of routes [21]. Technical specifications for elevators that provide shipment of grain lots for the formation of routes are presented in [25]. The average distance of to-elevator grain delivery by farmers increased from 19 to $51.5 \mathrm{~km}$ [22].

In general, despite the fact that the cost of grain production in the USA, as a rule, is higher than in the main competing countries, the effective logistics system ensures its competitiveness in world markets.

The logistic system of grain transportation in Canada underwent similar changes. In response to discounts provided by railways when increasing 
the amount of shipment, there occurred a consolidation of elevators. Between 1994 and 2003, the number of grain elevators decreased by $62 \%$, while their total loading capacity decreased by only $8 \%$.

The domestic logistics system for the export of grain cargo is characterized by the dispersion of the grain loading over a large number of railway stations. So, at present in Ukraine grain loading is carried out at 630 stations, however, as the analysis of statistical data showed, for about 420 stations $(67 \%)$ the volumes of average daily grain loading do not exceed 1 wagon. In addition, the loading at some stations is extremely uneven: for example, only 24 stations $(4 \%)$ conducted the grain loading on more than half of the days a year, while $50 \%$ of the stations spent no more than 34 days a year for grain loading $[9,15]$.

The negative result of this is a significant turnover of wagons, which in 2016 was about 9.9 days [17], inefficient use of locomotive traction at the initial and final stages of transportation, significant operating costs associated with car servicing at stations. The existence of such a logistics system is possible because of the absence in Ukraine of differentiated tariff rates for wagon, group and route shipments, as well as the availability of stand-by grain hoppers in the 2000s. However, the combination of such factors as sharp increase in grain production, critical wear of grain carriers and stiffer competition in the world grain markets make it necessary to improve the logistics infrastructure and technologies for grain transportation. In these conditions, the experience of the USA and Canada can be used in Ukraine, which consists in increasing the loading capacity of elevators, on the one hand, and using routes for the grain transportation with special tariffs, on the other hand.

\section{Purpose of the study}

The purpose of the study is to develop a methodology for the formation of a network of grain loading concentration areas to ensure the shipper routing of rail transportation of grain to the seaports of Ukraine for export.

\section{Methodology}

The choice of terminal elevators (junctions) and grain loading concentration areas is a very complex multivariate and multifactor optimization task.
At the same time, it is necessary to take into account the existing infrastructure of the junctions and the possibilities for its development, the volumes of grain loading at the stations, the additional costs associated with storing grain, unit train loading, delivering grain to junctions by road and the costs of transporting grain by rail to ports.

Formulation and formalization of the problem. The task of determining the areas of possible grain loading concentration and the corresponding junctions, where the grain will be loaded in unit trains, can be formulated as follows.

There are a lot of $S$ grain loading stations on the railway range $S=\left\{s_{1}, s_{2},-s_{i} s_{z}\right)$, where $z$-is the total number of grain loading stations. The distances $l_{i j}$ between each pair of stations $s_{i}$ and $s_{j}\left(s_{i}\right.$, $s_{j} \in S$ ) can be represented by the distance matrix $L$ [16]:

$$
L=\left|\begin{array}{cccc}
0 & l_{12} \ldots & l_{1 j} \ldots & l_{1 z} \\
l_{21} & 0 \ldots & l_{2 j} \ldots & l_{2 z} \\
\ldots & \ldots & \ldots & \ldots \\
l_{i 1} & l_{i 2} & l_{i j} \ldots & l_{i z} \\
\ldots & \ldots & \ldots & \ldots \\
l_{z 1} & l_{z 2} \ldots & l_{z j} \ldots & 0
\end{array}\right|
$$

Each element of the set $S$ (station) is characterized by a number of parameters and can be represented by the structure:

$$
s_{i}=\{I, N, c, q, p, \mathrm{~T}, \mathrm{~K}\},
$$

where $I$-station identifier (ECP code) [16]; $N-$ station name [16]; $c$-station class; $q$-average annual volume of grain loading, wag.; $p$-capacity of the elevator facility for one-time storage of grain, ths. tons; $\mathrm{T}$ - vector characterizing the distance from the station to the main seaports; $\mathrm{K}$ - vector characterizing the volume of additional capital investments for the development of the station infrastructure when loading grain unit trains.

Each element of the vector $\mathrm{T}$ is the number of the tariff zone corresponding to the distance from the given station $s_{i}\left(s_{i} \in S\right)$ to one of the seaports where grain is transshipped for export [7]:

$$
\mathrm{T}_{i}=\left\{t_{1}, t_{2}, \ldots . t_{n}\right\}
$$

Each element of the vector $\mathrm{K}$ corresponds to a certain amount of additional capital investments 
that are required for the development of the station (elevator and railway) infrastructure with the weekly loading of 1, 2 and 3 unit trains, respectively:

$$
\mathrm{K}_{i}=\left\{k_{1}, k_{2}, k_{3}\right\} .
$$

Average annual volumes of grain loading $q_{i}$ for each station are determined on the basis of statistical processing of the data obtained from UFACSUZ-E (Unified Freight Automated Control System of UZ). Data on the class of each station and the capacity of its elevator facility can be obtained from TIS of the stations using AWS TIS.

On the basis of the indicated initial data it is necessary:

- from the set $S$ to select a subset $S^{*}\left(S^{*} \subset S\right)$ of the junctions $s_{u}{ }^{*}\left(s_{u}{ }^{*} \in S^{*}, u=1,2, \ldots, m\right)$, where grain loading of unit trains will be carried out;

- for each junction $s_{u}{ }^{*}$ (type $\mathrm{U}$ ) to determine the loading concentration area $R_{u}(u=1,2, \ldots, m)$, i.e. a set of stations $s_{v} \in S$ (type $V$ ), from which the delivery of grain by road to the junction $s_{u}{ }^{*}$ will be organized:

$$
R_{u}=\left\{I_{r}, Q_{r}, s^{*}, s_{1}, s_{2}, \ldots, s_{v}, \ldots, s_{f}\right\}, s_{v} \in S,
$$

where $I_{r}$ - identifier of the concentration area; $Q_{r}$ - total annual grain loading at all stations of the area, wag.

When forming loading concentration areas, it is necessary to observe the following conditions:

- the distance from $U$-station $s_{u}{ }^{*}$ of the area $R_{u}$ to any $V$-station of the area $s_{v}\left(s_{v} \in R_{u}\right)$ must not exceed the maximum specified value $l_{\max }$ (when solving this task it is assumed that $l_{\max }=30 \mathrm{~km}$ ):

$$
\begin{aligned}
& \left(\forall s_{v} \in R_{u}\right)\left(\forall s_{u}^{*} \in R_{u}\right)\left(l_{u v} \leq l_{\max }\right), \\
& v=1,2, \ldots, f_{u}, u=1,2, \ldots, m
\end{aligned}
$$

- the total annual volume of the grain shipped at the concentration area stations $R_{u}$ must be not less than the minimum specified value $Q_{\min }$ (when solving this task, it is assumed that $Q_{\min }=3000$ wag/ year, which ensures the shipment of at least 1 unit train with grain per week):

$$
\left(\forall R_{u}\right)\left(Q_{r} \geq Q_{\min }\right), u=1,2, \ldots, m
$$

And, finally, the solution of the task of selecting junctions and areas of grain loading concentra- tion should ensure minimum total costs associated with the routing of grain transportation for export to ports. In aggregate, these costs can be represented as

$$
\begin{aligned}
& \sum_{u=1}^{m} E_{u}^{\mathrm{road}}+\sum_{u=1}^{m} E_{u}^{s t}+\sum_{u=1}^{m} E_{u}^{\mathrm{utr}}+ \\
& +\sum_{u=1}^{m} E_{u}^{c l}+\sum_{u=1}^{m} E_{u}^{\mathrm{inf}} \rightarrow \mathrm{min}
\end{aligned}
$$

where $E_{u}^{\text {road }}$ - additional costs for transportation of grain to the junction of the area $R_{u}$ by road, mln. $\mathrm{UAH} ; E_{u}^{\text {st }}$ - additional costs for grain storage at the junction of the area $R_{u}$ for making up a unit train, mln. UAH; $E_{u}^{\mathrm{utr}}-$ costs for transportation of grain to ports by unit trains from a junction of the area $R_{u}$, mln. UAH; $E_{u}^{\mathrm{cl}}-$ costs for carload transportation of grain to ports from the stations of the area $R_{u}$, mln. UAH; $E_{u}^{\text {inf }}$ - additional reduced costs associated with the development of elevator and rail infrastructure of the junction of the area $R_{u}$, mln. UAH.

The article describes the developed methodology for solving this problem, which is based on the methods of cluster analysis, set theory and multicriteria optimization.

\section{Findings}

Determination of junctions for loading of unit trains based on the cluster analysis. The solution of this problem involves the separation of the initial set of grain loading stations $S$ into two subsets $-S^{*}$, which includes junctions of possible loading concentration ( $U$-stations), and $S^{\prime}$, which includes stations where the loading of grain routes is impractical. Considering the significant number of grain loading stations (more than 600), cluster analysis methods can be used effectively to obtain these subsets $[6,13]$.

Cluster analysis is a method of grouping (classifying) multidimensional objects, based on the representation of the results of individual observations by points of a suitable geometric space with the subsequent allocation of clusters of these points. The task of cluster analysis methods is to select such homogeneous spaces in the original multidimensional data that the objects within the 
cluster are "similar" in a certain sense to each other, and objects from different clusters are "not similar".

To select the set of junctions $S^{*}$, an agglomerate algorithm of direct classification was used [6]. In agglomeration algorithms, unlike divisive algorithms, each classifiable object in the beginning is a separate cluster. At each step of the algorithm, the two closest clusters are combined. This happens until the number of clusters reaches the certain, in most cases, the predetermined value (in our case, two clusters). It is advisable to use divisive algorithms when the initial population must be divided into a sufficiently large number of clusters (more than 10) [13], which does not correspond to the conditions of the problem of grain loading station classification.

An important factor in the effectiveness of cluster analysis is the choice of parameters by which the classification of objects (in this case, railway stations) is performed. As noted in [6], with the increase in the number of indicators used to classify objects, its quality is reduced. In this connection, from the set of parameters characterizing the freight station (2), based on the methods of dispersion analysis and Sheffe multiple comparisons [1], and taking into account the expert estimates, the following informative parameters were singled out: station class $-c$, annual volume of grain loading $q$, available capacity of elevator infrastructure $-p$, additional costs for the development of elevator and railway infrastructure to ensure the loading of grain unit trains $-k_{1}, k_{2}, k_{3}$. It should be noted that obtaining of specific values of the vector $k_{1}, k_{2}, k_{3}$ in monetary terms for each station is a very laborious task. In this connection, the authors used parameterized dimensionless values $k_{1}, k_{2}, k_{3}$ in the range $[0 ; 1]$; while $k_{j}=0$ means that additional funds are not required for the station infrastructure development to form $j$ of grain unit trains per week, and $k_{j}=1-$ formation of $j$ of grain unit trains per week at a given station is impractical due to the need for significant investments in infrastructure, in the rest of the cases $-0<k_{j}<1$. The specific values of the parameters $k_{1}, k_{2}, k_{3}$ for each station are determined expertly on the basis of the analysis of its infrastructure.

Since the information parameters of the stations selected for classification are measured in different units and have different ranges of values, we carried out their standardization. For this purpose, the effectiveness of several methods for standardizing data considered in $[3,13,19]$ was researched. Herewith, the "reference" classification was performed expertly, during which a set of 35 grain loading stations were divided into two clusters: $U$ stations and $V$-stations. The effectiveness of each of the standardization methods was evaluated according to two criteria: probability of erroneous classification $-P_{\text {er }}$ (as compared to a "reference") and value of the total intragroup dispersion $-D_{\mathrm{gr}}$. The studies performed on a computer with the help of the "Statistica" package showed that the best results $\left(P_{\mathrm{er}}=4-7 \%\right)$ were obtained with the standardization of data by maximum and by range, the worst results were obtained with standardization by dispersion.

During classification, an important role is also played by the choice of the distance between the individual objects. The distance between the two objects $a$ and $b$ is the value of the distance $d_{a b}$, which is the greater, the less similar are the objects $a$ and $b$. When choosing the method of classification to obtain the training sample, we compared 6 distances in order to determine the most suitable for the solution of the problem posed $[6,13,19]$ : the Euclidean distance, the Manhattan distance, the Brey-Curtis distance, the Chebyshev distance, the Canberra distance, the power distance.

To select the most effective distance with the help of the "Statistica" package, their comparative analysis was performed while classifying the "reference" set of stations. The effectiveness of each distance was also assessed by the indicators $P_{\text {er }}$ and $D_{\mathrm{gr}}$. The study of the distance effectiveness showed that the best quality of the classification of grain loading stations was obtained using the "Canberra" distance $\left(P_{\mathrm{er}}=3-5 \%\right)$. The worst results were obtained using the Chebyshev distance $\left(P_{\mathrm{er}}=30\right.$ $35 \%)$.

At each step of the agglomeration algorithm of the cluster analysis, two clusters are combined, the distance between which is minimal. This raises the problem of determining the distances between individual clusters. The method of calculating this distance is determined by the adopted cluster strategy. When determining the most effective classification algorithm, we studied seven cluster methods 
[3, 6, 19]: "nearest neighbor", "furthest neighbor", "group mean", "centroid", "quadratic", "flexible", Ward's method. The comparative analysis of the application of these methods for the classification of the "reference" set of grain loading stations, performed with the help of the "Statistica" package, showed that the closest results to the "reference" classification were obtained using the "flexible" unification method and Ward's method $\left(P_{\mathrm{er}}=5\right.$ $7 \%)$. The worst results were obtained using the methods of "nearest" and "furthest" neighbor $\left(P_{\text {er }}=25-35 \%\right)$.

Thus, using the agglomeration cluster analysis method based on the "flexible" unification method and the "Canberra" distance between objects, the initial set of grain loading stations $S$ was divided into two subsets $-S^{*}$, which includes the junctions of possible loading concentration ( $U$ - Station) -43 stations in total, and $S^{\prime}$, which includes the stations where the loading of grain unit trains is not relevant -587 stations in total.

Determination of areas of possible grain load- ing concentration. Based on the found subset of junction stations $S^{*}$ the areas of possible grain loading concentration $R_{u}(5)$ are formed, according to the territorial proximity of $V$-stations to the junction $U$-station (6). For each junction station $s_{u}{ }^{*}$ at the first step of the formation procedure of the corresponding area $R_{u}$ (5): $Q_{r}=q_{u}, f=0,\left(Q_{r} \in R_{u}, f \in R_{u}\right.$, $\left.q_{u} \in S_{u}{ }^{*}\right)$. Next, the $i$-th row of the distance matrix $L$ (1) corresponding to the station $s_{u}{ }^{*}$ is analyzed and those stations $s_{j} \in S(j=1,2,-z)$, for which the condition $l_{i j} \leq l_{\max }(6)$ is true, are included in the set $R_{u}$. At the same time for the area $R_{u}$ the following parameters are recalculated:

$$
Q_{r}=Q_{r}+q_{j}, f=f+1,\left(q_{j} \in s_{j}\right) .
$$

With the help of this procedure, the set $R=\left\{R_{1}\right.$, $\left.R_{2}, \ldots, R_{u}, \ldots, R_{m}\right\}$ was formed, which includes 43 areas $(m=43)$ of the possible grain loading concentration (Table 1).

Table 1

Areas of possible grain loading concentration

\begin{tabular}{c|c|c|c|c|c}
\hline No. & Region & Junction station $s_{u}{ }^{*}$ & $\begin{array}{c}\text { Total loading, } \\
\text { wag / year }\end{array}$ & $\begin{array}{c}\text { Loading at } \\
\text { station } s_{u}{ }^{*}, \\
\text { wag / year }\end{array}$ & $\begin{array}{c}\text { Stations of loading concentra- } \\
\text { tion area } R_{u}\end{array}$ \\
\hline 1 & 2 & 3 & 4 & 5 & 6 \\
\hline 1 & Chernihiv & Linovitsyi & 9831 & 2288 & Priluki, Piryatin \\
\hline 3 & Cherkasy & Drabovo-Baryat. & 8897 & 2905 & $\begin{array}{c}\text { Palmira, Maryanovka, } \\
\text { Grebenka }\end{array}$ \\
\hline 4 & Poltava & Priluki & 8496 & 5675 & Linovitsyi, Galka \\
\hline 5 & Poltava & Yuskovtsyi & 8175 & 1077 & $\begin{array}{c}\text { Drabovo-Baryatinskaya, } \\
\text { Maryanovka, } \\
\text { Piryatin, Lazorki }\end{array}$ \\
\hline 6 & Cherkasy & Uman & $\begin{array}{c}\text { Sula, Belovodyi, } \\
\text { Andreyashevka, Lokhvitsa }\end{array}$ \\
\hline 7 & Cherkasy & Palmira & 8119 & 3089 & $\begin{array}{c}\text { Drabovo-Baryatinskaya, } \\
\text { Zolotonosha-1 }\end{array}$ \\
\hline 8 & Poltava & Romodan & 7895 & 3110 & Mirgorod, Horol, Sencha \\
\hline 9 & Poltava & Piryatin & 7708 & 1868 & $\begin{array}{c}\text { Maryanovka, Linovitsy, Lazorki, } \\
\text { Grebenka }\end{array}$ \\
\hline
\end{tabular}


Continuation of table 1

\begin{tabular}{|c|c|c|c|c|c|}
\hline 10 & Cherkasy & Maryanovka & 7676 & 2538 & $\begin{array}{l}\text { Drabovo-Baryatinskaya, } \\
\text { Piryatin, Grebenka }\end{array}$ \\
\hline 11 & Cherkasy & Nosovka & 7353 & 2426 & Nezhin, Bobrovitsyi \\
\hline 12 & Sumy & Toropilovka & 7121 & 5016 & $\begin{array}{c}\text { Sumy, Syrovatka, Basyi, } \\
\text { Golovashevka }\end{array}$ \\
\hline 13 & Sumy & Sumy & 7121 & 1047 & $\begin{array}{c}\text { Toropilovka, Syrovatka, } \\
\text { Basyi, Golovashevka }\end{array}$ \\
\hline 14 & Sumy & Syrovatka & 7010 & 590 & $\begin{array}{l}\text { Basyi, Toropilovka, Sumy, } \\
\text { Boromlya }\end{array}$ \\
\hline 15 & Cherkasy & Hristinovka & 6876 & 5134 & Uman, Monastyrishche \\
\hline 16 & Poltava & Mirgorod & 6813 & 3273 & $\begin{array}{l}\text { Romodan, Gogolevo, } \\
\text { Melashenkovo }\end{array}$ \\
\hline 17 & Poltava & Sula & 6744 & 4417 & $\begin{array}{l}\text { Yuskovtsyi, Andreyashevka } \\
\text { Lohvitsa, Sencha }\end{array}$ \\
\hline 18 & Kirovohrad & Aleksandriya & 5875 & 732 & $\begin{array}{l}\text { Koristovka, Korolevka, } \\
\text { Pantaevka, Schastlivaya }\end{array}$ \\
\hline 19 & Cherkasy & Monastyrishche & 5725 & 591 & Hristinovka \\
\hline 20 & Kirovohrad & Korolevka & 5632 & 708 & $\begin{array}{c}\text { Schastlivaya, Koristovka, } \\
\text { Aleksandriya }\end{array}$ \\
\hline 21 & Sumy & Belovodyi & 5495 & 1835 & $\begin{array}{l}\text { Romnyi, Yuskovtsyi, } \\
\text { Andreyashevka }\end{array}$ \\
\hline 22 & Cherkasy & Zolotonosha 1 & 5214 & 2125 & Zolotonosha 1, Palmira \\
\hline 23 & Poltava & Horol & 4768 & 1108 & $\begin{array}{c}\text { Romodan, Veselyiy Podol, } \\
\text { Petrovka }\end{array}$ \\
\hline 24 & Sumy & Romnyi & 4418 & 2154 & Belovodyi, Andreyashevka \\
\hline 25 & Kirovohrad & Novoukrainka & 4221 & 1537 & $\begin{array}{c}\text { Pomoshnaya, Kapustino, } \\
\text { Pletenyiy Tashlyik }\end{array}$ \\
\hline 26 & Kiev & Ustinovka & 4106 & 866 & Fastov-1, Belaya Tserkov \\
\hline 27 & Poltava & Seleshchina & 4105 & 1683 & Karlovka, Bozhkov \\
\hline 28 & Poltava & Karlovka & 4020 & 2251 & Seleschina, Lannaya \\
\hline 29 & Kiev & Yagotin & 3911 & 3911 & - \\
\hline 30 & Cherkasy & Gorodishche & 3823 & 418 & $\begin{array}{l}\text { Korsun, Signaevka, } \\
\text { Tsvetkovo }\end{array}$ \\
\hline 31 & Kirovohrad & Koristovka & 3758 & 2075 & $\begin{array}{c}\text { Aleksandriya, Korolevka, } \\
\text { Pantaevka }\end{array}$ \\
\hline 32 & Vinnytsia & Kryzhopol & 3640 & 1197 & $\begin{array}{l}\text { Vapnyarka, Knyazhevo, } \\
\text { Popelyuhi }\end{array}$ \\
\hline 33 & Lugansk & Starobelsk & 3570 & 3570 & - \\
\hline
\end{tabular}


End of the table 1

\begin{tabular}{c|c|c|c|c|c}
\hline 34 & Kirovohrad & Pomoshnaya & 3498 & 1563 & $\begin{array}{c}\text { Novoukrainka, } \\
\text { Lyudmilovka }\end{array}$ \\
\hline 35 & Poltava & Reshetilovka & 3494 & 3064 & $\begin{array}{c}\text { Fedunka, Sagaydak, } \\
\text { Brateshki, Umantsevka }\end{array}$ \\
\hline 36 & Vinnytsia & Vapnyarka & 3423 & 1494 & Knyazhevo, Kryizhopol \\
\hline 37 & Vinnytsia & Knyazhevo & 3423 & 732 & Vapnyarka, Kryizhopol \\
\hline 38 & Khmelnitsky & Kamenets-Podol. & 3248 & 3248 & - \\
\hline 39 & Kharkiv & Savintsy & 3163 & 1955 & Zakomelskaya, Balakleya \\
\hline 40 & Kharkiv & Zakomel'skaya & 3149 & 824 & Savintsyi, Izyum \\
\hline 41 & Poltava & Globino & 3108 & 2237 & Veselyiy Podol, Rublevka \\
\hline 42 & Cherkasy & Kamenka & 2948 & 880 & $\begin{array}{c}\text { Im. Tarasa Shevchenko, } \\
\text { Fundukleevka }\end{array}$ \\
\hline 43 & Kirovohrad & Kapitanovka & 2833 & 350 & $\begin{array}{c}\text { Signaevka, Novomirgorod, } \\
\text { Serdyukovka }\end{array}$
\end{tabular}

In total $m=43$ areas included $n=82$ stations: 43 junction ( $U$-stations) and 39 non-junction ( $V$ - stations). The condition (6) is not fulfilled for the remaining non-junction stations, i.e. they are located from the nearest junction station at a distance greater than $l_{\max }$.

For each formed concentration area $R_{u}\left(R_{u} \subset R\right)$ the condition (7) is checked i.e. the sufficiency of the total annual volume of grain loading at the stations of the area for sending of at least one grain unit train per week from the corresponding junction station $s_{u}{ }^{*}$. If the condition (7) is not fulfilled, then this area is excluded from further calculations. As can be seen from Table 1, the total volumes of annual grain loading in concentration areas on the basis of Kamenka and Kapitanovka stations are less than $Q_{\min }=3000 \mathrm{wag} /$ year; therefore, the areas $R_{42}$ and $R_{43}$ are excluded. Thus, in the list of $m=41$ area there are $n=76$ stations (41 junction $U$-station and 35 non-junction $V$-stations). It should also be noted that some areas include only junction stations: $R_{29}$ (Yagotin), $R_{33}$ (Starobelsk) and $R_{38}$ (Kamenets-Podolskiy), own grain loading at which exceeds $Q_{\text {min }}$.

Selection of effective areas of grain loading concentration. Analysis of Table 1 shows that the majority of the obtained sets $R_{u}(u=1,2, \ldots, 41)$ are overlapping, i.e. one or several elements (stations) of one set (area) are simultaneously elements of other sets (areas). For example, Lazorka nonjunction station belongs to the areas $R_{4}$ (Grebenka) and $R_{9}$ (Piryatin), while Linovitsyi junction, in addition to the $R_{1}$ area, is also part of the areas $R_{3}$ (Priluki) and $R_{9}$ (Piryatin). At the same time, there are several disjoint sets, the elements of which are part of only one set, for example, $R_{11}$ (Nosovka), $R_{29}$ (Yagotin).

Thus, in the resulting set $R$ it is necessary to select the subset $R^{*}$, all of $m^{*}$ elements of which (loading concentration areas $R_{u}, u=1,2, \ldots, m^{*}$ ) are mutually disjoint sets. Herewith, the total volume of grain loading in the final subset $R^{*}$ must be the maximum, and the total amount of costs associated with the concentration of grain loading and the making up of grain unit trains must be minimal (3), i.e.:

$$
\left\{\begin{array} { l } 
{ Q ( R ^ { * } ) \rightarrow \operatorname { m a x } } \\
{ E ( R ^ { * } ) \rightarrow \operatorname { m i n } }
\end{array} \Rightarrow \left\{\begin{array}{l}
\sum_{i=1}^{m^{*}} Q_{r(i)} \rightarrow \max \\
\sum_{i=1}^{m^{*}} E_{i} \rightarrow \min
\end{array}\right.\right.
$$

The required subset $R^{*} \subset R$ is the union of disjoint sets $R_{u}^{*}\left(u=1,2, \ldots, m^{*}\right)$, for which the objective function (4) reaches an extremum.

To solve this problem, the following procedure was developed. Initially, disjoint and overlapping 
subsets $R_{u}(u=1,2, \ldots, m)$ are distinguished in the original set $R$ (Table 1). For this purpose, one of the DSU (disjoint set union) algorithms can be used $[2,12]$. The result of this algorithm is the matrix $G=\left|g_{u v}\right|(u=1,2, \ldots, m ; v=1,2, \ldots, m)$, where each row $u$ and column $v$ correspond to a certain set (concentration area) $R_{u}$ and $R_{v}$, respectively (Table 1), and each element of the matrix $g_{u v}$ is a list of stations $s_{i}\left(s_{i} \in S\right)$, which are simultaneously included in the areas (sets) of $R_{u}$ and $R_{v}$. In case if $g_{u v}=\{\varnothing\}$, the sets $R_{u}$ and $R_{v}$ are disjoint and are included in the resulting subset $R^{*} \subset R$. If $g_{u v} \neq$ $\{\varnothing\}$, then the sets $R_{u}$ and $R_{v}$ are overlapping; herewith the following options are possible:

- common elements of the sets $R_{u}$ and $R_{v}$ are only junction $U$-stations (for example, areas of concentration $R_{32}$-Kryzhopol, $R_{36}$-Vapnyarka, $R_{37}$ - Knyazhevo);

- common elements of the sets $R_{u}$ and $R_{v}$ are only non-junction $V$-stations (for example, Andreashevka station for the areas $R_{17}-$ Sula and $R_{24}-$ Romnyi);

- common elements of the sets $R_{u}$ and $R_{v}$ are both junction and non-junction stations (for example, the areas $R_{12}$-Toropilovka and $R_{24}$ - Sumy).

It is necessary to redistribute common elements for all pairs of overlapping sets $R_{u}$ and on their basis to form such sets $R_{u}^{*}$, that the objective function (4) reaches an extremum. The above problem (4) can be solved by methods of the optimal set partitioning theory [8]; however, these methods are rather laborious and require a considerable amount of computation. The specificity of this problem allows us to obtain a solution by more simple methods.

We transform the matrix $G$ into the matrix $X=\left|x_{u t}\right|(u=1,2, \ldots, m ; t=1,2, \ldots, n)$, in which each row $u$ corresponds to a certain set (area) $R_{u}$ (Table 1), and each column $t$ - to a definite $U$ station or $V$-station. Each element of the matrix is the Boolean variable $x_{u t}=\{0 ; 1\}$, which takes the values $x_{u t}=1$, if the station $s_{t}$ can be included in the concentration area $R_{u}\left(s_{t} \in R_{u}\right)$, and $x_{u t}=0$ otherwise $\left(s_{t} \notin R_{u}\right)$. Each station $s_{t}$ corresponds to a certain value of the average annual amount of grain loading $q_{t}(1)$, as well as a certain parameter $e_{u t}$, which characterizes the value of additional costs when the station $s_{t}$ is included in the loading concentration area $R_{u}$. st $\mathrm{Ru}$. The objective function
(4) in this case takes the following form:

$$
\left\{\begin{array}{l}
\sum_{u=1}^{m} \sum_{t=1}^{n} q_{t} x_{u t} \rightarrow \max \\
\sum_{u=1}^{m} \sum_{t=1}^{n} e_{u t} x_{u t} \rightarrow \min
\end{array} \Rightarrow\left(\begin{array}{l}
\sum_{u=1}^{m} \sum_{t=1}^{n} q_{t} x_{u t} \\
-\sum_{u=1}^{m} \sum_{t=1}^{n} e_{u t} x_{u t}
\end{array}\right) \rightarrow \max \right.
$$

It should be noted that determining the values of the parameter $e_{u t}$ for each grain loading station directly in monetary terms is a very complex and time-consuming task. In this connection we accepted the parameterized scale of values $e_{u t}\{1$; $10\}$, when $e_{u t}=1$ corresponds to the minimum level of additional costs when including station $s_{t}$ into the concentration area $R_{u}^{*}$, and $e_{u t}=10$ - to the maximum. The specific values of $e_{u t}$ for each station at the stage of preliminary calculations are determined expertly.

Let us state the constraints of the problem:

$$
\begin{gathered}
\left(\forall s_{t}\right)\left(\sum_{u=1}^{m} x_{u t} \leq 1\right), t=1,2, \ldots, n \\
\left(\forall R_{u}^{*}\right)\left(\sum_{t=1}^{n} q_{t} x_{u t} \geq Q_{\min } \vee \sum_{t=1}^{n} q_{t} x_{u t}=0\right), u=1,2, \ldots, m \\
\left(\forall s_{t} \notin R_{u}\right)\left(x_{u t}=0\right), u=1,2, \ldots, m ; t=1,2, \ldots, n
\end{gathered}
$$

The constraint (6) means that each station $s_{t}$ can be included in not more than one concentration area $R_{u}^{*}$, but it can be included in no area. The constraint (7) determines that the total volume of loading for each concentration area $R_{u}^{*}$ must not be less than $Q_{\min }$ (2), otherwise this region is excluded, and the stations included in it are redistributed among other areas. The constraint (8) excludes the possibility of adding the station $s_{t}$ to the area $R_{u}^{*}$, if this is not provided in the original set $R$ (see Table $1)$.

The problem (5)-(8) in the above formulation is a multi-criteria (vector) optimization problem [18]; herewith, the peculiarities of the problem make it possible to assign it to problems of integer-linear programming with Boolean variables [11], for the solution of which it is expedient to transfer to a one-criterion optimization problem. For this purpose, we used the method of linear convolution with the standardization of criteria [5]; the objec- 
tive function (11) in this case takes the following form:

$$
\left(w_{q} \sum_{u=1}^{m} \sum_{t=1}^{n} q_{t}^{0} x_{u t}-w_{e} \sum_{u=1}^{m} \sum_{t=1}^{n} e_{u t}^{0} x_{u t}\right) \rightarrow \max ,
$$

where $q_{t}^{0}, e_{u t}^{0}-$ normalized values of the parameters of grain loading stations; $w_{q}, w_{e}-$ weight coefficients of the optimization criteria, the specific values of which (in the range $[0 ; 1]$ ) are determined expertly

The resulting problem was solved with the help of the simplex method, modified for problems with Boolean variables [11]. As a result, the subset $R^{*}$, was formed, which is a union of disjoint sets $R_{u}^{*}$; each such set $R_{u}^{*}$ corresponds to a certain area, where the grain loading concentration is the most effective (Table 2).

Table 2

\section{Effective areas of grain loading concentration}

\begin{tabular}{|c|c|c|c|}
\hline No. & Multiple junction $s_{u}{ }^{*}$ & Stations of loading concentration area $R_{u}^{*}$ & $\begin{array}{c}\text { Total loading, } \\
\text { wag/year }\end{array}$ \\
\hline 1 & Drabovo-Baryatinskaya & Maryanovka, Grebenka & 5808 \\
\hline 2 & Priluki & Galka & 6208 \\
\hline 3 & Uman & Potash & 3014 \\
\hline 4 & Romodan & Horol, Sencha & 4622 \\
\hline 5 & Piryatin & Linovitsyi, Lazorki & 4805 \\
\hline 6 & Nosovka & Nezhin, Bobrovitsyi & 7353 \\
\hline 7 & Toropilovka & Sumy, Syirovatka, Basyi, Golovashevka & 7121 \\
\hline 8 & Hristinovka & Monastyirische & 5725 \\
\hline 9 & Mirgorod & Gogolevo, Melashenkovo & 3703 \\
\hline 10 & Sula & Yuskovtsyi, Lohvitsa & 5911 \\
\hline 11 & Aleksandriya & Koristovka, Korolevka, Pantaevka, Schastlivaya & 5875 \\
\hline 12 & Zolotonosha 1 & Zolotonosha-1, Palmira & 5214 \\
\hline 13 & Romnyi & Belovodyi, Andreyashevka & 4418 \\
\hline 14 & Ustinovka & Fastov-1, Belaya Tserkov & 4106 \\
\hline 15 & Karlovka & Seleschina, Lannaya & 4020 \\
\hline 16 & Yagotin & - & 3911 \\
\hline 17 & Gorodishche & Korsun, Signaevka, Tsvetkovo & 3823 \\
\hline 18 & Kryzhopol & Vapnyarka, Knyazhevo, Popelyuhi & 3640 \\
\hline 19 & Starobelsk & - & 3570 \\
\hline 20 & Pomoshnaya & Novoukrainka, Lyudmilovka & 3498 \\
\hline 21 & Reshetilovka & Fedunka, Sagaydak, Brateshki, Umantsevka & 3494 \\
\hline 22 & Kamenets-Podolskiy & - & 3248 \\
\hline 23 & Zakomel'skaya & Savintsyi, Izyum & 3149 \\
\hline 24 & Globino & Veselyiy Podol, Rublevka & 3108 \\
\hline
\end{tabular}


In the final solution, 70 stations are included in 24 grain loading concentration areas, which, with minimal additional costs, provides the maximum total volume of grain loading by unit trains with 109344 wag. per year.

\section{Originality and practical value}

The originality of the work lies in the fact that the authors, based on the modern mathematical apparatus of cluster analysis, set theory and multicriteria optimization, developed the methodology for the formation of grain loading concentration areas on the Ukrainian railways network that takes into account both infrastructure-technological and economic factors.

Application of the developed method of grain loading concentration for the formation of unit trains will significantly reduce the logistics costs in the supply chain of grain to Ukrainian ports for export and, consequently, increase its competitiveness in foreign markets.

\section{Conclusions}

The performed researches allow drawing the following conclusions.

1. Ukraine is one of the world's largest grain exporters. At the same time, one of the main problems in the export of Ukrainian grain is a high share of logistics costs, which reaches $35 \%$ of the final cost of production.

2. More than $95 \%$ of the grain is exported through the seaports of Ukraine, whereto the delivery is carried out mainly by rail transport by carload. One of the ways to reduce costs in the logistics chain of grain delivery to ports is the routing of rail traffic. The experience of the USA and Canada shows that the introduction of grain unit trains allows reducing the share of logistics costs up to $9 \%$.

3. To organize the shipper routing of grain transportation by rail it is necessary to form a network of terminal elevators for grain loading concentration. Delivery of grain from linear to terminal elevators can be carried out by road.

4. The selection of junction stations and grain loading concentration areas is a complex task, which is proposed to be solved on the basis of cluster analysis, set theory and multi-criteria optimization.

5. Using the developed methodology, there are selected 24 areas of possible grain loading concentration on the Ukrainian rail network, which cover 70 stations and, with a minimum additional cost, provide for about 110,000 ths. wag. per year of unit trains (more than 7 million tons of grain).

\section{LIST OF REFERENCE LINKS}

1. Алгоритмы: построение и анализ / Т. Кормен, Ч. Лейзерсон, Р. Ривест, К. Штайн. - Москва : ООО «И. Д. Вильямс», 2013. - 1328 с.

2. Андерсон, Т. В. Введение в многомерный статистический анализ / Т. В. Андерсон. - Москва : Физматгиз, 1963. - 360 с.

3. Ахо, А. Построение и анализ вычислительных алгоритмов / А. Ахо, Дж. Хопкрофт, Дж. Ульман. Москва : Мир, 1979. - 536 с.

4. Вернигора, Р. В. Оценка уровня профессиональной подготовки дежурных по станции с использованием компьютерных тренажеров / Р. В. Вернигора, В. В. Малашкин // Транспортні системи і технології перевезень : зб. наук. пр. Дніпропетр. нац. ун-ту залізн. трансп. ім. акад. В. Лазаряна. - Дніпропетровськ, 2015. - Вип. 10. - С. 29-37.

5. Дюран, Б. Кластерный анализ / Б. Дюран, П. Оделл. - Москва : Книга по требованию, 2012. - 128 с.

6. Енергетичний баланс України за 2015 рік [Electronic resource] / Державна служба статистики України. Available at: http://ukrstat.gov.ua/operativ/operativ2016/energ/en_bal/Bal_2015_u.zip. - Title from the screen. - Accessed : 03.03.2017.

7. Зак, Ю. А. Прикладные задачи многокритериальной оптимизации / Ю. А. Зак. - Москва : Экономика, 2014. $-455 \mathrm{c}$.

8. Збірник тарифів на перевезення вантажів залізничним транспортом у межах України та повязані з ними послуги. - Київ : ТОВ «Інпрес», 2009. - 200 с. 


\section{ЕКСПЛУАТАЦІЯ ТА РЕМОНТ ЗАСОБІВ ТРАНСПОРТУ}

9. Киселева, Е. М. Модели и методы решения непрерывных задач оптимального разбиения множеств: линейные, нелинейные, динамические задачи : монография / Е. М. Киселева, Л. С. Коряшкина. - Киев : Наук. думка, 2013. - 607 с.

10. Козаченко, Д. М. Удосконалення технічного забезпечення та технологій експортних перевезень зернових вантажів в Україні / Д. М. Козаченко, Р. Г. Коробйова, Р. Ш. Рустамов // Вісн. Дніпропетр. держ. аграрно-економ. ун-ту. - 2015. - № 4. - С. 121-127.

11. Колодійчук, В. А. Ефективність логістики зерна та продуктів його переробки : монографія / В. А. Колодійчук. - Львів : Укр. бестселер, 2015. - 574 с.

12. Корбут, А. А. Дискретное программирование / А. А. Корбут, Ю. Ю. Финкельштейн. - Москва : Наука, 1969. - 368 c.

13. Мандель, И. А. Кластерный анализ / И. А. Мандель. - Москва : Финансы и статистика, 1988. - 215 с.

14. Обзор рынка зерновых [Electronic resource]. - Available at: http://www.igc.int/downloads/gmrsummary/gmrsummr.pdf. - Title from the screen. - Accessed : 03.03.2017.

15. Рустамов, Р. Ш. Оценка перспектив развития зерновой логистики в Украине / Р. Ш. Рустамов // Транспортні системи і технології перевезень : зб. наук. пр. Дніпропетр. нац. ун-ту залізн. трансп. ім. акад. В. Лазаряна. - Дніпропетровськ, 2014. - Вип. 8. - С. 127-133.

16. Тарифное руководство № 4 железных дорог Украины. - Киев : Логос, 2001. - 403 с.

17. Укрзализныця оценивает дефицит зерновозов в 500-1000 вагонов ежесуточно [Electronic resource]. Available at: http://cfts.org.ua/news/2016/10/06/ukrzaliznytsya_otsenivaet_defitsit_zernovozov_v_500_1000_ vagonov_ezhesutochno_36864. - Title from the screen. - Accessed : 03.03.2017.

18. Штойер, Р. Многокритериальная оптимизация. Теория, вычисления и приложения / Р. Штойер. Москва : Радио и связь, 1992. - 504 с.

19. Энслейн, К. Статические методы для ЭВМ / К. Энслейн. - Москва : Наука, 1986. - 464 с.

20. Hauser, R. J. Implicit Values of Multiple Car Grain Loading Facilities in Iowa and Nebraska / R. J. Hauser, J. Beaulieu, C. P. Baumel // North Central J. of Agricultural Economics. - 1984. - Vol. 6. - Iss. 2. - P. 80-90. doi: $10.2307 / 1349253$.

21. Hyland, M. Analytical models of rail transportation service in the grain supply chain: Deconstructing the operational and economic advantages of shuttle train service / M. Hyland, H. Mahmassani, L. Mjahed // Transportation Research, Part E: Logistics and Transportation Review. - 2016. - Vol. 93. - P. 294-315. doi: 10.1016/j.tre.2016.06.008.

22. Ndembe, E. Hard Red Spring Wheat Marketing: Effects of Increased Shuttle Train Movements on Railroad Pricing in the Northern Plains / E. Ndembe // J. of the Transportation Research Forum. - 2015. - Vol. 54, No. 2. - P. 101-115.

23. Nightengale, E. A. Some Effects of Recent Changes in the Railway Grain-Rate Structure on Interregional Competition and Regional Development / E. A. Nightengale, J. Davidson, H. Ottoson // Transportation Problems and Policies in the Trans-Missouri West. - Lincoln : University of Nebraska Press, 1967. P. 77-102.

24. Railroad Revitalization and Regulatory Reform Act of 1976 [Electronic resource] : Public Law 94-210, § 801. - Available at: http://www.legisworks.org/GPO/STATUTE-90-Pg31.pdf. - Title from the screen. - Accessed : 03.03.2017.

25. Sarmiento, C. Spatial Modeling in Technology Adoption Decisions: The Case of Shuttle Train Elevators / C. Sarmiento, W. Wilson // American J. of Agricultural Economics. - 2005. - Vol. 87. - Iss. 4. P. 1034-1045. doi: 10.1111/j.1467-8276.2005.00786.x.

26. Schnake, L. D. Inland grain elevator operating costs and capital requirements [Electronic resource] / L. D. Schnake, C. Jr. Stevensю // Kansas Agricultural Experiment Station. - 1983. - Bulletin 644. - P. 1-32. Available at: https://www.ksre.k-state.edu/historicpublications/pubs/SB644.pdf. - Title from the screen. Accessed : 03.03.2017.

27. Sparger, A. A comprehensive rail rate index for grain [Electronic resource] / A. Sparger, M. Prater. Available at: http://ageconsearch.umn.edu/bitstream/147348/2/Rail\%20Rate\%20Index.pdf. - Title from the screen. - Accessed : 03.03.2017.

28. Staggers Rail Act of 1980 [Electronic resource] : Public Law 96-448. - Available at: https://www.gpo.gov/fdsys/pkg/STATUTE-94/pdf/STATUTE-94-Pg1895.pdf. - Title from the screen. - Accessed : 03.03.2017. 
29. Wilson, W. U.S. grain handling and transportation system: factors contributing to the dynamic changes in the 1980s and 1990s [Electronic resource] / W. Wilson ; Dept. of Agricultural Economics, Agricultural Experiment Station, North Dakota State University. - Fargo, North Dakota, 1998. - 27 p. - Available at: http://ageconsearch.umn.edu/bitstream/23081/1/ae98004.pdf. - Title from the screen. - Accessed : 03.03.2017.

\section{Д. М. КОЗАЧЕНКО ${ }^{1 *}$, Р. В. ВЕРНИГОРА ${ }^{2 *}$, Р. Ш. РУСТАМОВ ${ }^{3 *}$}

${ }^{1 *}$ Науково-дослідна частина, Дніпропетровський національний університет залізничного транспорту імені академіка В. Лазаряна, вул. Лазаряна, 2, Дніпро, Україна, 49010, тел. +38 (056) 37351 09, ел. пошта kozachenko@upp.diit.edu.ua, ORCID 0000-0003-2611-1350

${ }^{2 *}$ Каф. «Станції та вузли», Дніпропетровський національний університет залізничного транспорту імені академіка В. Лазаряна, вул. Лазаряна, 2, Дніпро, Україна, 49010, тел. +38 (056) 37315 12, ел. пошта rv.vernigora@gmail.com, ORCID 0000-0001-7618-4617

3* Регіональна філія «Одеська залізниця ПАТ «Укрзалізниця», вул. Пантелеймонівська, 19, Одеса, Україна, 65012, тел. +38 (048) 72730 96, ел. пошта rustamovrsh@gmail.com, ORCID 0000-0002-5860-1840

\section{СТВОРЕННЯ ЕКСПОРТНО-ОРІЕНТОВАНОЇ МЕРЕЖІ ЕЛЕВАТОРІВ В УКРАЇ̈I}

Мета. В науковій роботі необхідно дослідити питання підвищення ефективності експортних залізничних перевезень зернових вантажів в Україні за рахунок впровадження відправницької маршрутизації та концентрації навантаження зерна на вузлових елеваторах. Методика. Як свідчить досвід США й Канади, одним із ефективних напрямків зниження витрат у логістичному ланцюзі доставки зерна в порти $є$ відправницька маршрутизація залізничних перевезень. Відправницька маршрутизація перевезень зернових вантажів передбачає концентрацію їх навантаження на вузлових станціях. Вибір вузлових станцій пропонується здійснювати 3 використанням методів кластерного аналізу. Для формування районів концентрації навантаження зерна використані методи теорії множин і багатокритеріальної оптимізації. Результати. На основі агломеративного алгоритму кластерного аналізу на мережі залізниць України виділені вузлові станції та сформовані райони можливої концентрації навантаження зерна. 3 використанням DSU-алгоритму виділені пересічні й непересічні райони концентрації. Задача вибору непересічних районів концентрації навантаження зерна формалізована як задача багатокритеріального цілочислового програмування 3 булевими змінними. У результаті розв'язання цієї задачі за допомогою модифікованого симплекс-методу на мережі залізниць України виділено 24 райони можливої концентрації навантаження зерна, які охоплюють 70 станцій та при мінімальних додаткових витратах забезпечують відправницьку маршрутизацію близько 7,5 млн т. зерна в рік. Наукова новизна. На основі сучасного математичного апарата авторами розроблена методика вибору вузлових станцій та районів концентрації навантаження зернових вантажів на мережі залізниць України 3 урахуванням економічної ефективності процесу. Практична значимість. Застосування розробленої методики концентрації навантаження зерна для формування відправницьких маршрутів дозволить суттєво знизити логістичні витрати в ланцюзі постачання українського зерна в морські порти на експорт i, відповідно, підвищити його конкурентоспроможність на зовнішніх ринках.

Ключові слова: експорт зерна; елеватори; залізничні перевезення; відправницька маршрутизація; концентрація навантаження

\footnotetext{
Д. Н. КОЗАЧЕНКО ${ }^{1 *}$, Р. В. ВЕРНИГОРА ${ }^{2 *}$, Р. Ш. РУСТАМОВ ${ }^{3 *}$

${ }^{1 *}$ Научно-исследовательская часть, Днепропетровский национальный университет железнодорожного транспорта имени академика В. Лазаряна, ул. Лазаряна, 2, Днипро, Украина, 49010, тел. +38 (056) 37351 09,

эл. почта kozachenko@upp.diit.edu.ua, ORCID 0000-0003-2611-1350

${ }^{2 *}$ Каф. «Станции и узлы», Днепропетровский национальный университет железнодорожного транспорта имени академика В. Лазаряна, ул. Лазаряна, 2, Днипро, Украина, 49010, тел. +38 (056) 37315 12,

эл. почта rv.vernigora@gmail.com, ORCID 0000-0001-7618-4617

${ }^{3 *}$ Региональный филиал «Одесская железная дорога» ПАО «Укрзализныця», ул. Пантелеймоновская, 19,

Одесса, Украина, 65012, тел. +38 (048) 72730 96, эл. почта rustamovrsh@gmail.com, ORCID 0000-0002-5860-1840
} 


\section{СОЗДАНИЕ ЭКСПОРТНО-ОРИЕНТИРОВАННОЙ СЕТИ ЭЛЕВАТОРОВ В УКРАИНЕ}

Цель. В научной работе необходимо рассмотреть вопрос повышения эффективности экспортных железнодорожных перевозок зерновых грузов в Украине за счет внедрения отправительской маршрутизации и концентрации погрузки зерна на узловых элеваторах. Методика. Как свидетельствует опыт США и Канады, одним из эффективных направлений снижения расходов в логистической цепи доставки зерна в порты является отправительская маршрутизация железнодорожных перевозок. Отправительская маршрутизация перевозок зерновых грузов предусматривает концентрацию их погрузки на узловых станциях. Выбор узловых станций предлагается осуществлять с использованием методов кластерного анализа. Для формирования районов концентрации погрузки зерна использованы методы теории множеств и многокритериальной оптимизации. Результаты. На основе агломеративного алгоритма кластерного анализа на сети железных дорог Украины выделены узловые станции и сформированы районы возможной концентрации погрузки зерна. C использованием DSU-алгоритма выделены пересекающиеся и непересекающиеся районы концентрации. Задача выбора непересекающихся районов концентрации погрузки зерна формализована как задача многокритериального целочисленного программирования с булевыми переменными. В результате решения этой задачи с помощью модифицированного симплексметода на сети железных дорог Украины выделено 24 района возможной концентрации погрузки зерна, которые охватывают 70 станций и при минимальных дополнительных расходах обеспечивают отправительскую маршрутизацию около 7,5 млн т. зерна в год. Научная новизна. На основе современного математического аппарата авторами разработана методика выбора узловых станций и районов концентрации погрузки зерновых грузов на сети железных дорог Украины с учетом экономической эффективности процесса. Практическая значимость. Применение разработанной методики концентрации погрузки зерна для формирования отправительских маршрутов позволит существенно снизить логистические расходы в цепи поставки украинского зерна в морские порты на экспорт и, соответственно, повысить его конкурентоспособность на внешних рынках.

Ключевые слова: экспорт зерна; элеваторы; железнодорожные перевозки; отправительская маршрутизация; концентрация погрузки

\section{REFERENCES}

1. Cormen, T. H., Leiserson, C. E.; Rivest, R. L., \& Stein, C. (2013). Introduction to Algorithms (3rd ed.). Moscow: I. D. Vilyams.

2. Anderson, T. V. (1963). Vvedeniye v mnogomernyy statisticheskiy analiz. Moscow: Fizmatgiz.

3. Aho, A. V., Hopcroft, J. E., \& Ullman, J. D. (1979). The design and analysis of computer algorithms. Moscow: Mir.

4. Vernigora, R. V., \& Malashkin, V. V. (2015). Assessment training level of railway dispatchers using computer simulators. Transport Systems and Transportation Technologies, 10, 29-37. doi: 10.15802/tstt2015/57063

5. Duran, B. S., \& Odell. P. L. (2012). Cluster Analysis. Moscow: Kniga po trebovaniyu.

6. State Statistics Service of Ukraine. (2016). Energy balance of Ukraine for 2015 year. Retrieved from http://ukrstat.gov.ua/operativ/operativ2016/energ/en_bal/Bal_2015_u.zip

7. Zak, Y. A. (2014). Prikladnyye zadachi mnogokriterialnoy optimizatsii. Moscow: Ekonomika.

8. Ministry of Infrastructure of Ukraine. (2009). Zbirnyk taryfiv na perevezennia vantazhiv zaliznychnym transportom u mezhakh Ukrainy ta poviazani z nymy posluhy. Kyiv: TOV «Inpres».

9. Kiseleva, Y. M., \& Koryashkina, L. S. (2013). Modeli i metody resheniya nepreryvnykh zadach optimalnogo razbieniya mnozhestv: lineynyye, nelineynyye, dinamicheskiye zadachi. Kyiv: Naukova dumka.

10. Kozachenko, D. M., Korobyova, R., \& Rustamov, R. (2015). Improving of technical means and technologies of grain transportation for export in Ukraine. Visnyk Dnipropetrovs'kogo derzhavnogo agrarno-economichnogo universytetu, 4, 121-127.

11. Kolodiichuk, V. A. (2015). Efektyvnist lohistyky zerna ta produktiv yoho pererobky. Lviv: Ukrainskyi bestseler.

12. Korbut, A. A., \& Finkelshteyn, Y. Y. (1969). Diskretnoye programmirovaniye. Moscow: Nauka.

13. Mandel, I. A. (1988). Klasternyy analiz. Moscow: Finansy i statistika.

14. International Grains Council. (2016 November, 24). Obzor rynka zernovykh. Retrieved from http://www.igc.int/downloads/gmrsummary/gmrsummr.pdf 
15. Rustamov, R. (2014). The assessment of the prospects for the development of grain logistics in Ukraine. Transport Systems and Transportation Technologies, 8, 127-133. doi: 10.15802/tstt2014/38101

16. Ministry of Infrastructure of Ukraine. (2001). Tarifnoye rukovodstvo №4 zheleznykh dorog Ukrainy. Kyiv: Logos.

17. Centre for Transport Strategies. (2016 October, 06). Ukrzaliznytsya otsenivayet defitsit zernovozov v 500-1000 vagonov ezhesutochno. Retrieved from http://cfts.org.ua/news/2016/10/06/ukrzaliznytsya_otsenivaet_defitsit_zernovozov_v_500_1000_vagonov_ezhe sutochno 36864

18. Shtoyer, $\bar{R}$. (1992). Mnogokriterialnaya optimizatsiya. Teoriya, vychisleniya i prilozheniya. Moscow: Radio i svyaz.

19. Ensleyn, K. (1986). Staticheskiye metody dlya EVM. Moscow: Nauka.

20. Hauser, R. J., Beaulieu, J., \& Baumel, C. P. (1984). Implicit Values of Multiple Car Grain Loading Facilities in Iowa and Nebraska. North Central Journal of Agricultural Economics, 6(2), 80-90. doi: 10.2307/1349253

21. Hyland, M., Mahmassani, H., \& Mjahed L. (2016). Analytical models of rail transportation service in the grain supply chain: Deconstructing the operational and economic advantages of shuttle train service. Transportation Research, Part E: Logistics and Transportation Review, 93, 294-315. doi: 10.1016/j.tre.2016.06.008

22. Ndembe, E. (2015). Hard Red Spring Wheat Marketing: Effects of Increased Shuttle Train Movements on Railroad Pricing in the Northern Plains. Journal of the Transportation Research Forum, 54(2), 101-115.

23. Nightengale, E. A., Davidson, J., \& Ottoson, H. (1967). Some Effects of Recent Changes in the Railway GrainRate Structure on Interregional Competition and Regional Development. Transportation Problems and Policies in the Trans-Missouri West, 77-102.

24. Railroad Revitalization and Regulatory Reform Act, Public Law 94-210, § 801. (1976). Retrieved from http://www.legisworks.org/GPO/STATUTE-90-Pg31.pdf

25. Sarmiento, C., \& Wilson, W. W. (2005). Spatial Modeling in Technology Adoption Decisions: The Case of Shuttle Train Elevators. American Journal of Agricultural Economics, 87(4), 1034-1045. doi: 10.1111/j.14678276.2005.00786.x

26. Schnake, L. D., \& Stevens, C. A. (1983). Inland grain elevator operating costs and capital requirements. Bulletin: Kansas Agricultural Experiment Station, 644. Retrieved from https://www.ksre.kstate.edu/historicpublications/pubs/SB644.pdf

27. Sparger, A., \& Prater M. E. (2013). A comprehensive rail rate index for grain. U.S. Department of Agriculture. doi: 10.9752/TS060.04-2013

28. Staggers Rail Act, Public Law 96-448. (1980). Retrieved from https://www.gpo.gov/fdsys/pkg/STATUTE94/pdf/STATUTE-94-Pg1895.pdf

29. Wilson, W. W. (1998). U.S. grain handling and transportation system: factors contributing to the dynamic changes in the 1980s and 1990s. Fargo, North Dakota: Department of Agricultural Economics, Agricultural Experiment Station, North Dakota State University. Retrieved from http://ageconsearch.umn.edu/bitstream/23081/1/ae98004.pdf

Prof. V. I. Bobrovskiy, D. Sc. (Tech.), (Ukraine), Prof. O. M. Ogar, D. Sc. (Tech.), (Ukraine) recommended this article to be published

Accessed: Dec. 15, 2016

Received: March 24, 2017 